\title{
Interaction between 3-Bromopyruvate and SC-5 I4 in prostate cancer treatment
}

\begin{abstract}
Background: Prostate cancer (PCA) is the second most diagnosed cancer in men. The high incidence of prostate cancer has been attributed to failures in single treatment of chemotherapy. Failure of mono treatment is mediated by heterogeneity and plasticity of prostate cancer cells. 3-Bromopyruvate is one of the most common chemotherapeutic drugs used for the treatment of prostate cancer. However, its clinical therapeutic efficiency has been limited due to numerous side effects and drug resistance. SC-514 is a relatively new drug. Very little information exists on the anti-cancer effects of SC-514. Nevertheless, SC-514 might be able to overcome side effects of conventional chemotherapy. 3-BPA is strong potentiators of chemotherapeutic drug. 3-BPA has the potential to potentiate the anti-cancer activity of SC-514. The combination of 3-BPA and SC-514 might be able to inhibit prostate cancer carcinogenesis despite existence of heterogeneity and plasticity of prostate cancer cells.
\end{abstract}

Objective of study: This study aims to investigate the potential interaction between 3-BPA and SC-514 during treatment of prostate cancer.

Method: The bioassays used in this study include: trypan blue exclusion, MTT tetrazolium, NBT, LDH cytotoxicity, and poly caspase assay. Combination Index (CI) calculation was used to investigate the antagonistic, synergistic or additive interaction between 3-BPA and SC-514. One-way ANOVA was utilized to compare the cytotoxic effects of 3-BPA, SC-514 and the combination of 3-BPA and SC-514 on DU-145 cells and PC-3 cells prostate cancer cells.

Results: Results suggested a weak negative $(r=-0.29)$ to moderate negative $(r=-0.42)$ correlation between ROS released and cell death. In addition, there was a weak correlation $(r=0.19)$ between percentage ROS induced and percentage apoptotic death. There was a positive correlation between the concentration of drug and cell death in DU-145 and PC-3 prostate cancer cells.

Conclusion: The overlap in mechanisms of action of 3-BPA and SC-514 increased the impact of SC-514 on prostate cancer cells. Hence, the combination of 3-BPA and SC-514 was more therapeutically effective (synergistic effect) than the single treatments of either 3-BPA or SC-514. The synergistic effect between 3-BPA and SC-514 did not occur by ROS induction. The apoptotic induction in DU-145 and PC-3 prostate cancer cells appears to occur via a mechanism other than reactive species (ROS) induction. This study suggests that the combination of 3-BPA and SC-514 as a therapeutic regimen can inhibit prostate cancer carcinogenesis effectively.
Volume 9 Issue 6 - 2018

Toluleke Oloruntobi Famuyiwa, Joubin Jebelli, James Kwasi Kumi Diaka,Waseem Asghar Department of Biological Sciences, Florida Atlantic University, USA

Department of Computer Engineering \& Electrical Engineering and Computer Science, Florida Atlantic University

Correspondence: Toluleke Oloruntobi Famuyiwa, Department of Biological Sciences, Florida Atlantic University, 3200 College Avenue, Davie, USA, Email tfamuyiva2014@fau.edu

Received: September 30, 2018 | Published: November 12, 2018

\section{Introduction}

\section{Prostate cancer}

Prostate cancer ( $\mathrm{PCa}$ ) still remains a medical challenge to the world ${ }^{1}$ and it is becoming a common disease in the world. ${ }^{2} \mathrm{PCa}$ account for $15 \%$ of all cancers in men worldwide. ${ }^{3}$ Prostate cancer is the most prevalent among the cancer related diseases and the second leading cause of cancer related death in USA. ${ }^{4}$ Prostate cancer poses a major economic limitation in humans. The economic limitation on patients makes prostate cancer one of the deadliest diseases. Patients with advanced stage of the disease have a low quality of life; they constantly visit the hospital for extremely expensive treatments. Regardless of the costly treatment of prostate cancer, there is life threatening transformations in the patient's body system..$^{5-7}$

The life-threatening transformation in the patient's system is because of uncontrollable division of the prostate cancer cells even after chemotherapy. Chemotherapy may be ineffective as a result of spontaneous accretion of tissues with polymorphous phenotype during treatment. ${ }^{2}$ This is illustrated in Figure 1A and 1B. The blue arrow represents epithelial cells and the red arrow represents fibroblastic cells. Biologically, prostate cancer cells possess six defining characteristic features that favor continuous proliferation. These features include invasion and metastasis, proliferative signaling, evasion of growth suppression, resistance to cell death, replicative immortality, and angiogenesis. ${ }^{8}$ These features differentiate them from healthy cells. ${ }^{8}$ Cancer researchers have made significant efforts to reduce deaths caused by prostate cancer. Conventional treatment modalities comprising radiotherapy, chemotherapy, gene therapy, immunotherapy, surgery and prostate specific membrane antigen (PSMA) targeted therapy have been developed to treat prostate and other human cancers. ${ }^{9-17}$ Unfortunately, the standard treatment 
regimens frequently destroy healthy cells and thus causes considerable harmful side effects. Specific challenges faced by chemotherapeutic agents in cancer treatment include poor solubility, rapid deactivation, restricted bio-distribution, low therapeutic index, severe side effects, poor pharmacokinetic and poor pharmacodynamics performance. ${ }^{2,18-21}$ Studies have shown that androgen dependent prostate cancer can

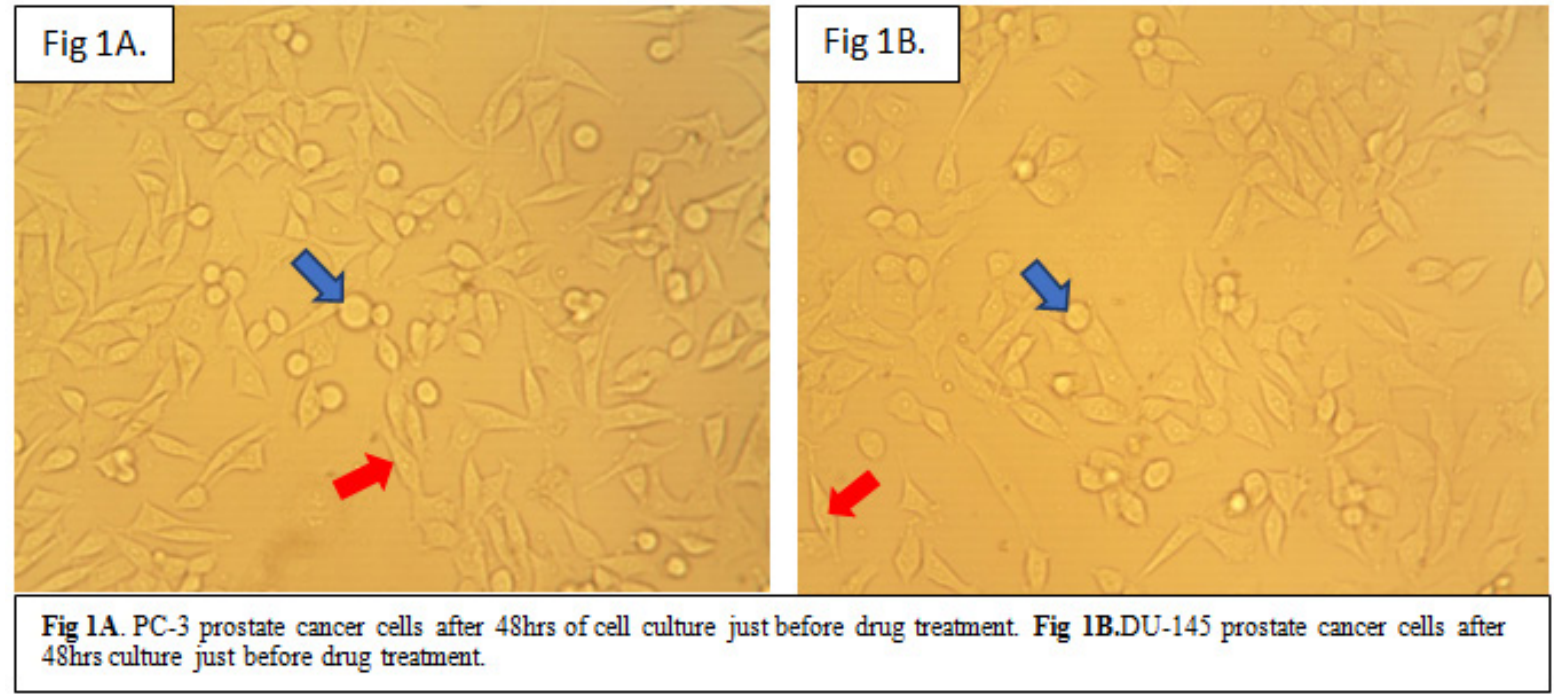

Comparison of metabolic activity in prostate cancer cells and normal prostate cells

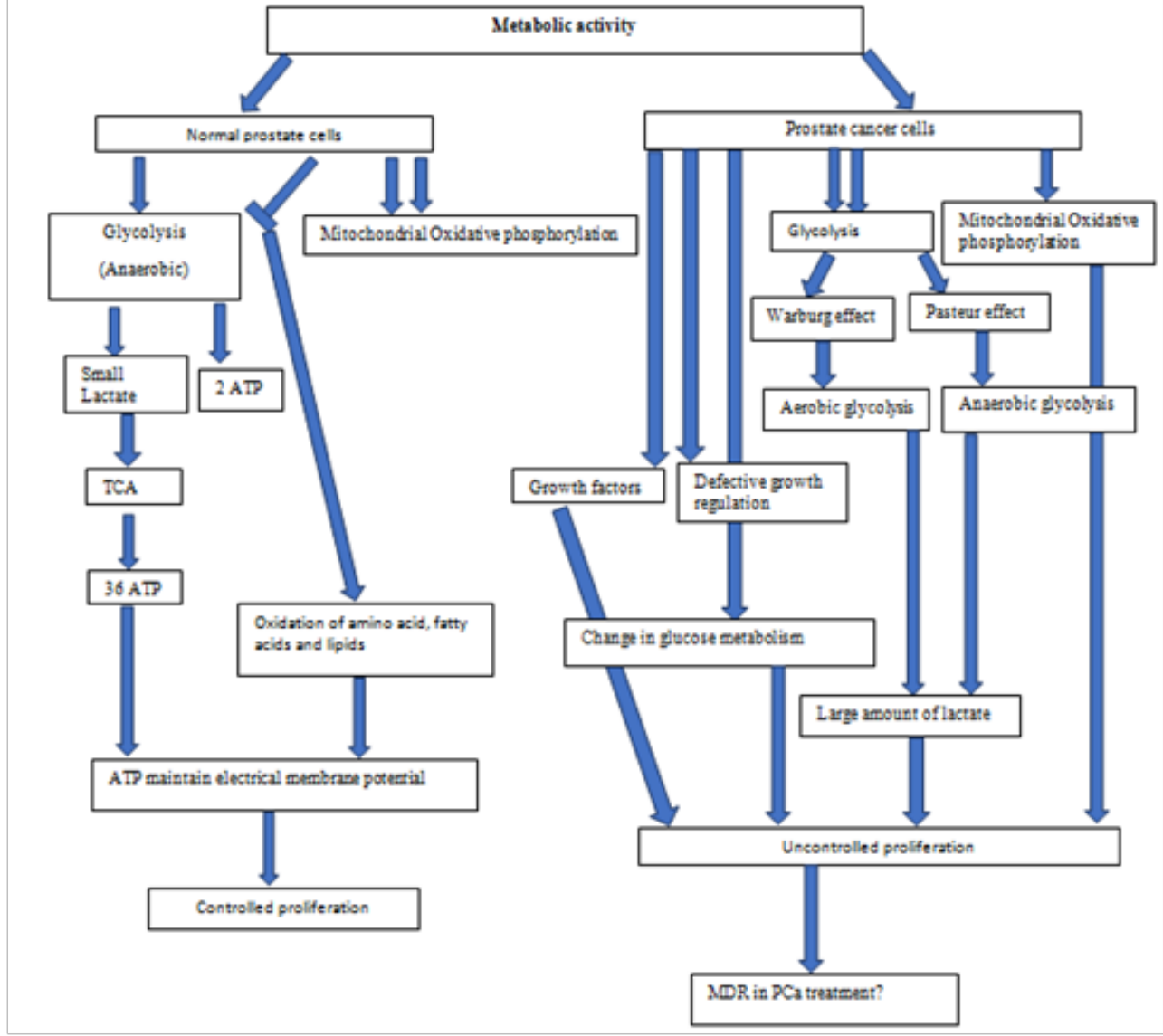

Figure 2 A clear knowledge of the mechanism of ATP production in prostate cancer cells and normal prostate cells is important in achieving better treatment outcome in combination therapy. ${ }^{29-40,42-58}$ 


\section{The mechanism of anticancer effects of 3-BPA}

A potent anticancer agent known as 3-Bromopyruvate (3-BPA) has been reported to inhibit ATP production in prostate cancer $(\mathrm{PCa})$ cells by targeting glycol sis, promoting mitochondrial destruction, and consequently increase oxidative stress. ${ }^{26} 3$-BPA is an antineoplastic compound that targets both the "Warburg effect", (elevated glycolysis even in the presence oxygen), as well as mitochondrial oxidative phosphorylation in cancer cells. ${ }^{27} 3-\mathrm{BPA}$ is a lactic acid analog of private (the simplest of the alpha keto acids and intermediate in several metabolic pathways), that is transported through the same mono carboxylate_transporters (MCT) as pyruvate..$^{28} 3$-BPA mimics lactic acid. Lactic acid is taken up by the cells' lactate transporters and inhibits hexokinase..$^{29} \mathrm{MCTs}$ are involved in the efflux of lactic acid out of the cells. ${ }^{27} \mathrm{~A}$ study suggested that 3-BPA uptake is particularly effective because of the overexpression of MCTs in PCa cells. ${ }^{30}$ The entry of 3-BPA is successfully achieved because lactic acid and 3-BPA differ in only a single atom (Br), making it impossible for the cancer cells' MCTs to distinguish between $\mathrm{Br}$ and $\mathrm{O} .{ }^{27}$ Once inside the PCa cells, 3-BPA inhibits glycolysis (2 ATP production machinery). Normal cells are not inhibited by 3-BPA, as they have a deficiency of MCTs. ${ }^{30,31}$ This deficiency does not allow 3-BPA to enter the normal cells easily. ${ }^{30,31}$

\section{Metabolic pathways influencing prostate cancer survival}

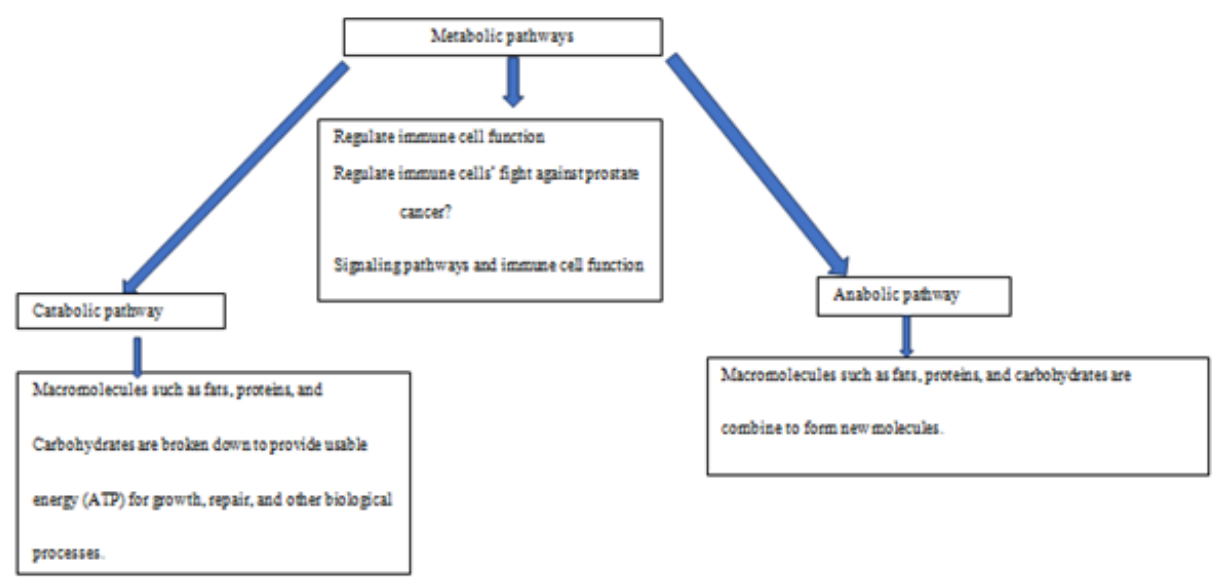

Figure 3 Metabolic pathways regulate the production of energy and nutrients for PCa cells' survival. This regulation may impact the immune system's fight against $\mathrm{PCa}$ in multiple ways . ${ }^{23-25}$

Furthermore, 3-BPA was shown to inhibit mitochondrial bound hexokinase II ( HKII). ${ }^{32}$ The mitochondrial phosphate transporter, that is essential for ATP synthesis is also inhibited by compounds reacting with sulfhydryl groups (-SH) such as 3-BPA. ${ }^{33}$ The second most important cellular target for 3-BPA is the Glyceraldehyde 3-phosphate dehydrogenase (GAPDH) enzyme. ${ }^{32-34}$ GAPDH like HK2 is also important for glycolysis. 3-BPA can compete with glucose in the first step of glucose conversion into glucose-6-phospate via the enzyme hexokinase II. 3-BPA inactivates HK II such that glucose cannot be metabolized any further in the glycolytic pathway, causing inhibition of glycolysis. ${ }^{32,35-37}$ Detailed examination of 3-BPA treated cells showed release of cytochrome $\mathrm{c}$ which is an apoptotic marker indicating that there has been a disruption of the mitochondrial membrane. ${ }^{38} 3$-BPA is a potent anti-glycolytic drug, able to induce severe ATP reduction and viability loss in many PCa cell lines, ${ }^{39}$ and it is less toxic to normal hepatocytes while depleting ATP in hepatocellular carcinoma (HCC) cells. ${ }^{40,41}$

Over the past 16years 3-BPA have been frequently studied as a promising antitumor agent. ${ }^{32,42} 3$-BPA regressed advance abdominal tumor. ${ }^{41}$ It eradicated xenograft tumors of HCC in all tested animals. ${ }^{41}$ There were no reported corrosive effects of 3 -BPA. ${ }^{43}$ Furthermore, 3 -BPA inhibits angiogenesis. ${ }^{44} 3$-BPA induced the reversal of cancer cell chemo-resistance, where 3-BPA was reported to inhibit the efflux of chemotherapy through the ATP-binding cassette transporters; and antagonized the P-glycoprotein-mediated efflux in cancer cells. $^{45-47}$ Multidrug resistance reversal, using 3-BPA might take place through decreasing ATP content in cancer cells, decreasing HK II activity, inhibiting ATPase activity, and reducing the expression of P-glycoprotein in chemo-resistant prostate cancer cells ${ }^{44,47,48}$ and thus results in a chemo-sensitization effect. ${ }^{16}$ Furthermore, 3-BPA has also been shown to inhibit cell viability by increasing reactive oxygen species (ROS) ${ }^{49,50}$ and inhibiting translation. ${ }^{51}$ The response to 3-BPA at $50 \mathrm{mM}$ and $100 \mathrm{mM}$ was dose-dependent, leading to loss of ATP at $65 \%$ and $90 \%$ loss, respectively. ${ }^{49}$ It was reported in the study that 3-BPA treated cells revealed an increase in cellular ROS levels. ${ }^{23}$ The properties of 3-BPA that promote mitochondrial destruction and increase in ROS, highlight its potential benefits in treatment of carcinoma. ${ }^{52}$ 3-BPA impacts rapid depletion of glutathione (GSH) pool, and consequent increase in cell oxidative stress. ${ }^{44,53-55}$ Clinically, 3-BPA kills prostate cancer cells, prevents cancer recurrence, and reduces chemo-resistance and radio-resistance commonly encountered in clinical oncology. ${ }^{48} 3$-BPA dramatically improve the therapeutic outcome of a patient having fibro lamellar hepatic carcinoma and/ or metastatic melanoma. ${ }^{56,57}$ Significant improvements in late stage cancer patients suggest the potential efficacy of 3-BPA to differentiate between tumor and healthy tissues..$^{58}$

\section{The mechanism of anticancer effects of SC-5 I 4}

Not much is known about SC-514. SC-514 is an orally active, ATP-competitive inhibitor of nuclear factor kappa-B kinase subunit beta inhibitor (IKK-2 or IKK $\beta$ ). SC-514 blocks nuclear factor Kappa-light-enhancer of activated B cells (NF- $\kappa \mathrm{B})$-dependent gene expression with IC-50 of $3-12 \mathrm{mM} .{ }^{59}$ Previous studies have also reported the inhibitory effects of SC-514 on IKK $\beta$ in the treatment of tumors and inflammation. ${ }^{60-69}$ However, the effect of SC- 514 on proliferation of PCa cell lines, multidrug resistance and RANKLinduced NF-kB signaling pathways is hitherto unknown. ROSinducing IKK $\beta$ inhibitor SC-514 enhanced nitrosourea-induced cell death in melanoma cells. ${ }^{70}$ SC-514 has been reported to be a selective IKK $\beta$ inhibitor and displayed $>10$-fold selectivity against 
28 other kinases, including both tyrosine kinases and other serinethreonine kinases. ${ }^{71}$ Inhibition of NF-KB pathway may influence cell survival. ${ }^{72-74}$ Although kinases have a number of similarities, $\operatorname{IKK} \beta$ has a 20 - to 50 -fold-higher level of kinase activity for $\operatorname{Ik} \beta$ than IKK $\alpha .^{75-79}$ Hence, this study investigates the impact of inhibitor of IKK $\beta$ on prostate cancer carcinogenesis. SC-514 dose-dependently inhibits RANKL-induced osteoclastogenesis with an IC-50 $<5 \mu \mathrm{M} .{ }^{80}$ SC-514 inhibits transcription of NF-kappa B-dependent genes in IL-1 beta-induced rheumatoid arthritis-derived synovial fibroblasts in a dose-dependent manner. ${ }^{59}$ At high concentrations, SC-514(12.5mM) induced apoptosis and caspase 3 activation in RAW 264.7 cells. Moreover, SC-514 specifically suppressed NF-kB activity owing to delayed RANKL-induced degradation of $\mathrm{IkB} \alpha$ and inhibition of p65 nuclear translocation. ${ }^{80}$ Studies indicates that SC-514 impairs RANKL-induced osteoclastogenesis and NF-kB activation. Consistent with this observation, blocking IKK $\beta$ kinase activity by SC-514 decreases the phosphorylation of p65/RelA at Ser-536 in human T-cell lymphotropic virus type I-transformed cells. ${ }^{64} \mathrm{Co}$-treatment of mouse skin with the IKK $\beta$-specific inhibitor SC-514 $(1 \mu \mathrm{M})$ attenuated TPAinduced activation of Akt and NF-kappaB, and also the expression of COX-2 in hairless mouse skin. ${ }^{63} \mathrm{SC}-514$ is a reversible and highly selective inhibitor of IKK-2. ${ }^{81} \mathrm{SC}-514$ inhibited proliferation of DU145 prostate cancer cells. ${ }^{82} \mathrm{SC}-514$ potentialized the effect of tyrosine receptor kinase (Axl) knockdown on proliferation (up to 10 fold) and apoptosis. ${ }^{82}$

\section{Methods}

Experiment 1: MTT Tetrazolium assay was performed to assess the cell viability of the prostate cancer cells after treatment with 3-BPA and/or SC-514. Results from this experiment will answer the question "will the combination of 3-BPA and SC-514 synergistically reduced cell viability compared to the single treatment of 3-BPA or SC-514"?

Briefly, prostate cancer cells (DU-145 and PC-3) were seeded at a density of 2500 cells /well in 96-well plate. These cells were incubated at $37{ }^{\circ} \mathrm{C}$ and $5 \% \mathrm{CO} 2$ for $48 \mathrm{hrs}$ (until they reach their $\log$ phase and $80-90 \%$ of confluence). These cells were treated with 3-BPA and/or SC-514 at their log phase for $48 \mathrm{hrs}$. $20 \mu 1$ of MTT (5 $\mu \mathrm{g} / \mathrm{ml}$ ) were added to the wells in the 96 well plate after the media was removed from the wells. The cells and MTT solution in the wells was incubated for $4 \mathrm{hrs}$ at $37^{\circ} \mathrm{C}$. The yellow tetrazolium MTT (3-(4, 5-dimethylthiazolyl-2)-2, 5-diphenyltetrazolium bromide) (Invitrogen) was reduced by metabolically active prostate cancer cells after drug treatment (3-BPA, SC-514 and 3-BPA + SC-514), by the action of dehydrogenase enzymes, to generate reducing equivalents such as NADH and NADPH. The resulting intracellular purple formazan was solubilized by adding $50 \mu \mathrm{l}$ DMSO to each well and quantified by spectrophotometric means using ELISA plate reader (Biotek ELx800). The absorbance was measured at $570 \mathrm{~nm}$. The absorbance values recorded was a measure of live cells in each well after drug treatment.

\section{Computation of the combination index for quantitative determination of drug interactions}

The percentage cell viability values from MTT Tetrazolium assay was used to determine drug interaction between 3-BPA and SC-514. The combination index values were used to quantify drug interactions between 3-BPA and SC-514. The classification of the interactions into categories of synergy, additivity, or antagonism was based on applying the formula in equation (1) and equation (2). Combination index (CI) analyses are widely used methods for evaluating drug interactions in combination cancer chemotherapy. ${ }^{83}$ The Loewe additivity model has been largely used as a reference model when the combined effect of two drugs is additive.

The model can be written as in Equation (1)

$$
(\mathrm{D})_{1} /(\mathrm{Dx})_{1}+(\mathrm{D})_{2} /(\mathrm{Dx})_{2}=1
$$

where (D), and (D), are the respective combination doses of drug 1(3-BPA) and drug 2(SC-514) that yielded an effect of $50 \%$ growth inhibition, with (Dx) and (Dx) $)_{2}$ being the corresponding single doses for drug 1( 3-BPA) and drug 2(SC-514) that resulted in the same effect, which is by definition the concentrations of drug 1(3-BPA) and drug 2 (SC-514) that will impact $60 \%$ reduction in cell viability. When Equation 1 holds, it can be concluded that the combined effect of the two drugs is additive. Based on Equation 1, the combination index, defined in Equation 2, can be used to classify drug interactions as synergistic, additive, or antagonistic.

Equation (2)

$$
\mathrm{CI}=(\mathrm{D})_{1} /(\mathrm{Dx})_{1}+(\mathrm{D})_{2} /(\mathrm{Dx})_{2}
$$

$\mathrm{CI}<1$ synergy; $\mathrm{CI}=1$ additivity; $\mathrm{CI} 1>$ antagonism

A CI of less than, equal to, and more than 1 indicates synergy, additivity, and antagonism, respectively. ${ }^{83}$

Experiment 2: To further evaluate the cytotoxic effects of 3-BPA and SC-514, we used Lactate Dehydrogenase (LDH) assay to quantify the LDH activity in the drug treated prostate cancer cells. This is a more sensitive assay to investigate the cell viability of the drug treated prostate cancer cells.

Lactate dehydrogenase (LDH) is a cytosolic enzyme present in prostate cancer cells. Plasma membrane damage releases LDH into the prostate cell culture media after treatment with 3-BPA and/or SC514. Extracellular LDH in the media was quantified by a coupled enzymatic reaction in which $\mathrm{LDH}$ catalyzes the conversion of lactate to pyruvate via NAD+ reduction to NADH. Diaphorase then uses NADH to reduce a tetrazolium salt (INT) to a red formazan product that can be measured at $490 \mathrm{~nm}$. The level of formazan formation is directly proportional to the amount of LDH released into the medium, which is indicative of extent of cytotoxicity after 3-BPA and/or SC-514 treatment. Briefly, cultured prostate cancer cells (DU145 and PC-3) were incubated with 3-BPA and/or SC-514 to induce cytotoxicity and subsequently release LDH. The LDH released into the medium was transferred to a new microtiter plate and mixed with reaction mixture. After a 30-minute room temperature incubation, reactions were stopped by adding stop solution. Absorbance at $490 \mathrm{~nm}$ and $630 \mathrm{~nm}$ were measured using a plate-reading spectrophotometer (Biotek ELx800) to determine LDH activity.

Experiment 3: After determining the cytotoxic effects of 3-BPA and/or SC-514. We initiated studies on the mechanism of action of 3-BPA and SC-514. This study indicated impairment in the biological activities of prostate cancer cells after drug treatment. Extremely low or high ROS levels in prostate cancer cells may be correlated to impaired cell functions. NBT assay was performed to measure the ROS level in the treated prostate cancer cells after treatment with 3-BPA and/or SC-514. This assay answers the question "will the combination of 3-BPA and SC-514 modulate ROS levels significantly compared to the single treatment of 3-BPA or SC-514?

The bioactivity of 3-BPA and/or SC-514 generated Superoxide ions $\left(\mathrm{O}_{2}^{-}\right)$. Superoxide ions $\left(\mathrm{O}_{2}-\right)$ converted NBT to NBT diformazan. 
On the other hand, SOD reduces the $\mathrm{O}_{2}^{-}$concentration and thereby lowers the rate of NBT-diformazan formation. The extent of reduction in the appearance of NBT diformazan is a measure of SOD activity present in the drug treated prostate cancer cells (DU-145 and PC3 ). Increase in absorbance reading from absorbance reader (Biotek ELx800) reflects an increased level of intracellular ROS in the drug treated prostate cancer cells.

Experiment 4: We further investigated the mode of cell death in 3-BPA and/or SC-514 treated prostate cancer cells by detecting caspase activity in the treated prostate cancer cells. Caspases activities are one of the indicators of apoptosis. Live red image-poly caspase detection assay was used to detect apoptosis in prostate cancer cells after treatment with 3-BPA and/or SC-514.

This assay is based on a fluorescent inhibitor of caspases (FLICA ${ }^{\mathrm{TM}}$ ) methodology, essentially an affinity label. The reagent associates a fluoromethyl ketone (FMK) moiety, which can react covalently with a cysteine, with a caspase-specific amine acid sequence. For poly caspases, this recognition sequence is valine-alanine-aspartic acid (VAD). A sulforhodamine group (SR) is attached as a reporter. The FLICA reagent is thought to interact with the enzymatic reactive center of an activated caspase via the recognition sequence, and then to attach covalently through the FMK moiety. The FLICA inhibitor is cell permeant and noncytotoxic. Unbound FLICA molecules diffuse out of the cell and are washed away; the remaining red-fluorescent signal is a direct measure of the amount of active caspase that was present at the time the inhibitor was added. The amount of caspase is an indication of the extent of apoptosis in the treated prostate cancer cells.

Briefly, 2500 cells/well were seeded in the 96 well microtiter plate and drug treatments was performed as described earlier. To estimate the number of cells with caspase activities, 100 cells were counted in five different fields under the fluorescence microscope. Percentage of cells showing caspase activities was calculated. The percentage of cells indicating caspase activity was plotted against the concentration of the drugs.

\section{Results and discussion}

\section{MTT Tetrazolium assay}

To evaluate the impact of 3-BPA and SC-514 on percentage cell viability of prostate cancer cells in vitro, $\mathrm{PCa}$ cells were treated with 3-BPA and/or SC-514. Results are shown in Figures 4A \& 4B.

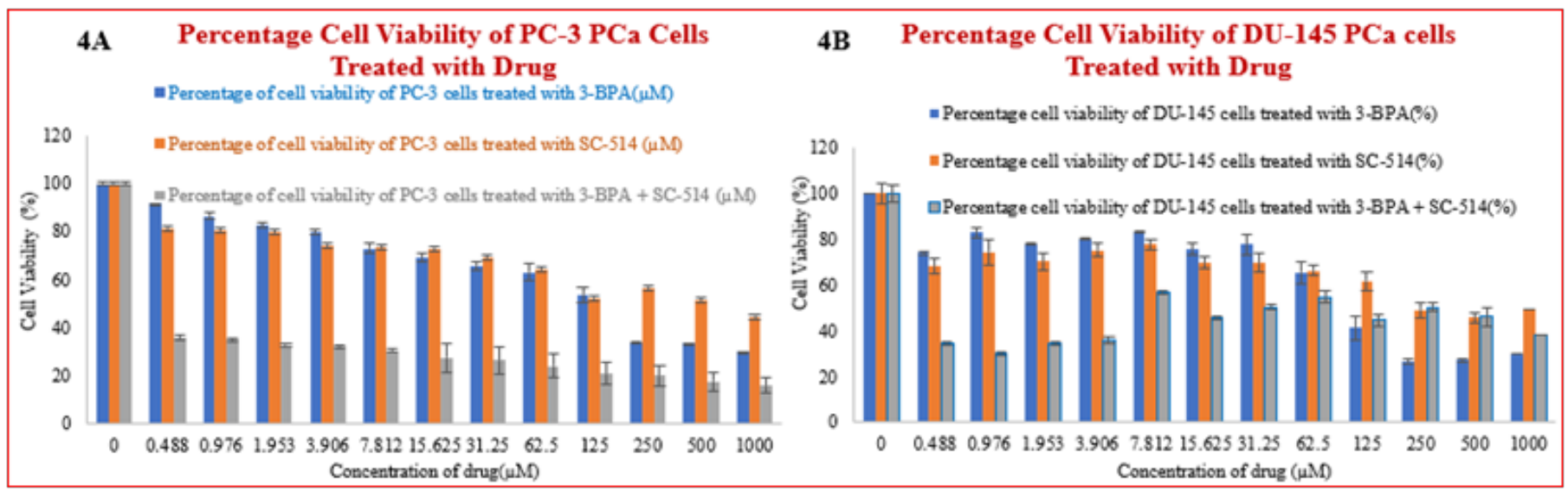

Figure 4 (A) Graph showing the percentage cell viability of PC-3 prostate cancer cells after 48hrs treatment with 3-BPA, SC-5I4 and 3-BPA + SC-5I4.

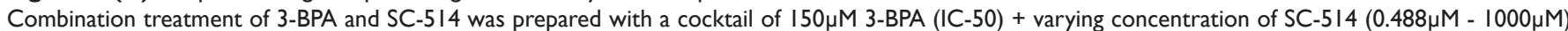
Data represented are the mean of $\pm S D$ of six independent experiments. A one-way anova analysis comparing the three treatment groups revealed a $p$-value $<0.01$. IC- 50 of SC-5I4 $=450 \mu \mathrm{M}$, IC-50 of 3-BPA $=150 \mu \mathrm{M}$. IC-50 of 3-BPA + SC-5I4 $=0.3 \mu \mathrm{M}$. Figure 4 (B) Graph showing the percentage cell viability of DU-I45 prostate cancer cells after 48hrs treatment with 3-BPA, SC-5I4 and 3-BPA + SC-5I4. Combination treatment of 3-BPA and SC-5I4 was prepared with a cocktail of II $10 \mu \mathrm{M} 3-B P A(I C-50)+$ varying concentration of SC-5I4 $(0.488 \mu \mathrm{M}-1000 \mu \mathrm{M})$. Data represented are the mean of $\pm S D$ of six independent experiments. Single factor one-way anova analysis comparing the three treatment groups revealed a p-value $<0.0$ I. IC-50 of SC-5I4 = 250 $\mu$ M, IC-50 of 3-BPA $=110 \mu \mathrm{M} \cdot \mathrm{IC}-50$ of $3-\mathrm{BPA}+\mathrm{SC}-514=15 \mu \mathrm{M}$.

\section{Calculation of combination index in DU-I45 Prostate cancer cells}

Equation (2)

$\mathrm{CI}=(\mathrm{D})_{1} /(\mathrm{Dx})_{1}+(\mathrm{D})_{2} /(\mathrm{Dx})_{2}$

Substituting values extrapolated from Figure 5 for equation (2):

(D) $1=110 \mu \mathrm{M},(\mathrm{Dx})_{1}=125 \mu \mathrm{M},(\mathrm{D})_{2=} 31.25 \mu \mathrm{M},(\mathrm{Dx})_{2=} 500 \mu \mathrm{M}$

$110 / 125+31.25 / 500=0.88+0.0625=0.9425$

Based on the standard that $\mathrm{CI}<=1$ synergy; $\mathrm{CI}=1$ additivity; $\mathrm{CI} 1$ $>$ antagonism. Combination treatment using SC-514 and 3-BPA was synergistic because $0.9425<1$.

\section{Calculation of combination index in PC-3 Prostate cancer cells}

Equation (2)

$\mathrm{CI}=(\mathrm{D})_{1} /(\mathrm{Dx})_{1}+(\mathrm{D})_{2} /(\mathrm{Dx})_{2}$

Substituting values extrapolated from Figure 5 for equation (2):

(D) $1=150 \mu \mathrm{M},(\mathrm{Dx})_{1}=187.5 \mu \mathrm{M},(\mathrm{D})_{2}=0.4 \mu \mathrm{M},(\mathrm{Dx})_{2}=1000 \mu \mathrm{M}$.

$150 / 187.5+0.4 / 1000=0.8+0.0004=0.8004$

Based on the standard that $\mathrm{CI}<=1$ synergy; $\mathrm{CI}=1$ additively; $\mathrm{CI} 1$ $>$ antagonism. Combination treatment using SC-514 and 3-BPA was synergistic because $0.8004<1$. 


\section{Lactate dehydrogenase (LDH) assay}

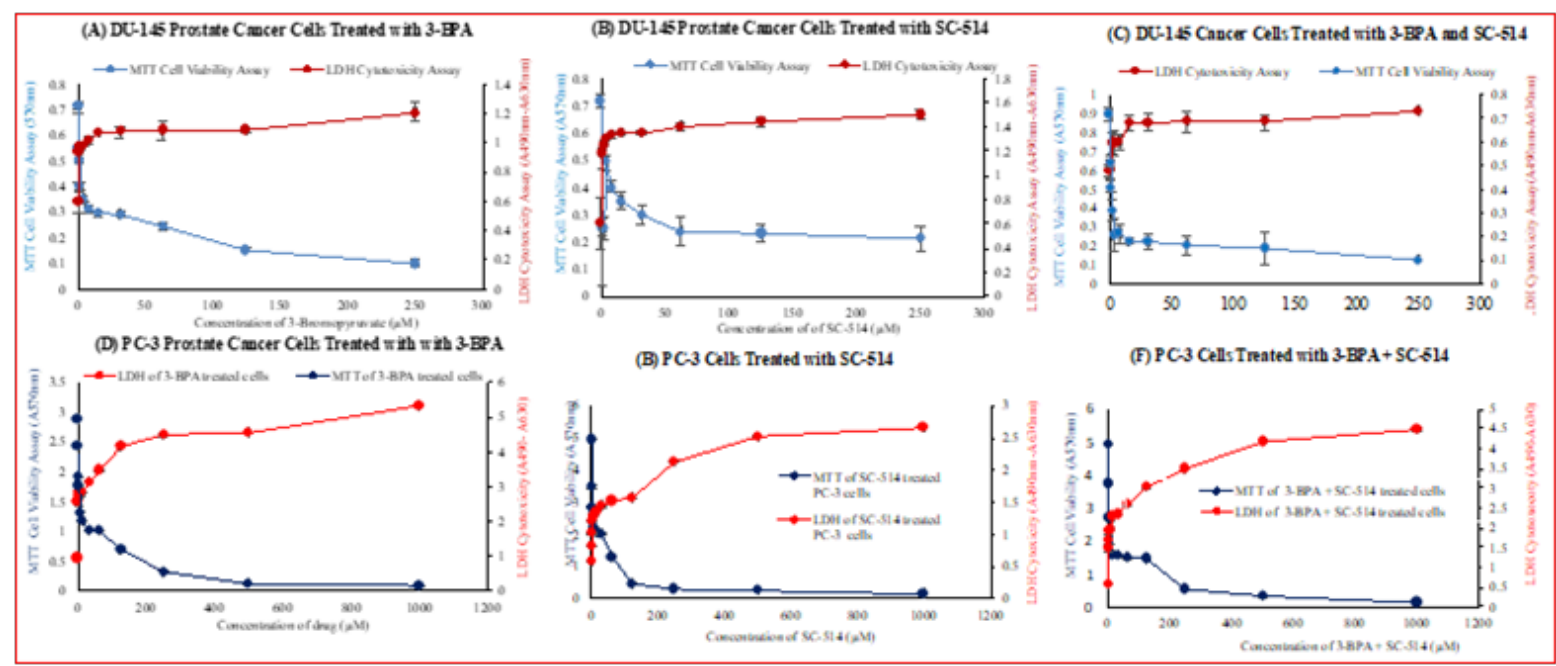

Figure 5 (A) Comparison of LDH cytotoxicity and MTT cell viability of 3-BPA treated DU-I 45 prostate cancer cells. DU-I45 prostate cancer cells (2500 cells per well) were plated in a 96 -well plate in DMEM medium supplemented with $10 \%$ fetal bovine serum and incubated at $37^{\circ} \mathrm{C}$ and $5 \% \mathrm{CO}$. After $48 \mathrm{hrs}$, varying concentrations of $3-\mathrm{BPA}(0.488 \mu \mathrm{M}, 0.976 \mu \mathrm{M}, \mathrm{I} .953 \mu \mathrm{M}, 3.906 \mu \mathrm{M}, 7.8 \mathrm{I} 2 \mu \mathrm{M}, 15.625 \mu \mathrm{M}, 3 \mathrm{I} .25 \mu \mathrm{M}, 62.5 \mu \mathrm{M}, \mathrm{I} 25 \mu \mathrm{M}, 250 \mu \mathrm{M})$ were added to the 96 well plates and incubated for $48 \mathrm{hrs}$ at $37^{\circ} \mathrm{C}$, and $5 \% \mathrm{CO}_{2}$ LDH Cytotoxicity was measured using the Pierce LDH cytotoxicity assay and cell viability measured by MTT cell proliferation assay. (B) Comparison of LDH cytotoxicity and MTT cell viability of SC-5I4 treated DU-I45 prostate cancer cells. DU-I45 prostate cancer cells ( 2500 cells per well) were plated in a 96 -well plate in DMEM medium supplemented with $10 \%$ fetal bovine serum and incubated at $37^{\circ} \mathrm{C}$ and $5 \% \mathrm{CO}_{2}$. After $48 \mathrm{hrs}$, varying concentrations of SC-5I $4(0.488 \mu \mathrm{M}, 0.976 \mu \mathrm{M}, \mathrm{I} .953 \mu \mathrm{M}, 3.906 \mu \mathrm{M}, 7.8 \mathrm{I} 2 \mu \mathrm{M}, \mathrm{I} 5.625 \mu \mathrm{M}, 3 \mathrm{I} .25 \mu \mathrm{M}, 62.5 \mu \mathrm{M}, \mathrm{I} 25 \mu \mathrm{M}, 250 \mu \mathrm{M})$ were added to the 96 well plates and incubated for $48 \mathrm{hrs}$ at $37^{\circ} \mathrm{C}$ and $5 \% \mathrm{CO}_{2}$. $\mathrm{LDH}$ Cytotoxicity was measured using the Pierce LDH cytotoxicity assay and cell viability measured by MTT cell proliferation assay. (C) Comparison of LDH cytotoxicity and MTT cell viability of 3-BPA + SC-5I4 treated DU-I45 prostate cancer cells. DU-I45 prostate cancer cells ( 2500 cells per well) were plated in a 96-well plate in DMEM medium supplemented with $10 \%$ fetal bovine serum and incubated at $37^{\circ} \mathrm{C}$ and $5 \% \mathrm{CO}_{2}$.After $48 \mathrm{hrs}$, varying concentrations of SC-5I $4(0.488 \mu \mathrm{M}, 0.976 \mu \mathrm{M}, \mathrm{I} .953 \mu \mathrm{M}, 3.906 \mu \mathrm{M}, 7.8 \mathrm{I} 2 \mu \mathrm{M}, \mathrm{I} 5.625 \mu \mathrm{M}, 3 \mathrm{I} .25 \mu \mathrm{M}, 62.5 \mu \mathrm{M}, \mathrm{I} 25 \mu \mathrm{M}, 250 \mu \mathrm{M})+\mathrm{II} 0 \mu \mathrm{M}$ 3-BPA (IC-50) were added to the 96 well plates and incubated for $48 \mathrm{hrs}$ at $37^{\circ} \mathrm{C}$ and $5 \% \mathrm{CO}_{2}$. LDH Cytotoxicity was measured using the Pierce LDH cytotoxicity assay and cell viability measured by MTT cell proliferation assay. (D) Comparison of LDH cytotoxicity and MTT cell viability of 3-BPA treated PC-3 prostate cancer cells. PC-3 prostate cancer cells ( 2500 cells per well) were plated in a 96 -well plate in DMEM medium supplemented with I0\% fetal bovine serum and incubated at $37^{\circ} \mathrm{C}$ and $5 \% \mathrm{CO}_{2}$. After $48 \mathrm{hrs}$, varying concentrations of 3-BPA $(0.488 \mu \mathrm{M}, 0.976 \mu \mathrm{M}, 1.953 \mu \mathrm{M}, 3.906 \mu \mathrm{M}, 7.8 \mathrm{I} 2 \mu \mathrm{M}, \mathrm{I} 5.625 \mu \mathrm{M}, 3 \mathrm{I} .25 \mu \mathrm{M}, 62.5 \mu \mathrm{M}$, $125 \mu \mathrm{M}, 250 \mu \mathrm{M}, 500 \mu \mathrm{M}, 1000 \mu \mathrm{M})$ were added to the 96 well plates and incubated for $48 \mathrm{hrs}$ at $37^{\circ} \mathrm{C}$, and $5 \% \mathrm{CO}, \mathrm{LDH} \mathrm{Cytotoxicity}$ was measured using the Pierce LDH cytotoxicity assay and cell viability measured by MTT cell proliferation assay. (E) Comparison of LDH cytotoxicity and MTT cell viability of SC-5I 4 treated PC-3 prostate cancer cells. PC-3 prostate cancer cells ( 2500 cells per well) were plated in a 96 -well plate in DMEM medium supplemented with I0\% fetal bovine serum and incubated at $37^{\circ} \mathrm{C}$ and $5 \% \mathrm{CO}_{2}$. After $48 \mathrm{hrs}$, varying concentrations of SC-5I4 $(0.488 \mu \mathrm{M}, 0.976 \mu \mathrm{M}, \mathrm{I} .953 \mu \mathrm{M}, 3.906 \mu \mathrm{M}, 7.8 \mathrm{I} 2 \mu \mathrm{M}, \mathrm{I} 5.625 \mu \mathrm{M}$, $31.25 \mu \mathrm{M}, 62.5 \mu \mathrm{M}, 125 \mu \mathrm{M}, 250 \mu \mathrm{M}, 500 \mu \mathrm{M}, 1000 \mu \mathrm{M})$ were added to the 96 well plates and incubated for $48 \mathrm{hrs}$ at $37^{\circ} \mathrm{C}$, and $5 \% \mathrm{CO}$, LDH Cytotoxicity was measured using the Pierce LDH cytotoxicity assay and cell viability measured by MTT cell proliferation assay. (F) Comparison of LDH cytotoxicity and MTT cell viability of 3-BPA + SC-5I 4 treated PC-3 prostate cancer cells. PC-3 prostate cancer cells (2500 cells per well) were plated in a $96-$ well plate in DMEM medium supplemented with $10 \%$ fetal bovine serum and incubated at $37^{\circ} \mathrm{C}$ and $5 \% \mathrm{CO}_{2}$. After $48 \mathrm{hrs}$, varying concentrations of SC-5I4 $(0.488 \mu \mathrm{M}, 0.976 \mu \mathrm{M}, 1.953 \mu \mathrm{M}$,

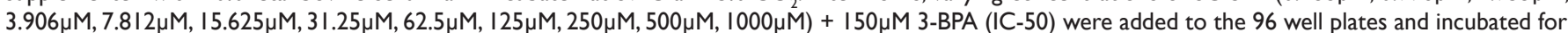
$48 \mathrm{hrs}$ at $37^{\circ} \mathrm{C}$, and $5 \% \mathrm{CO}_{2}$. LDH Cytotoxicity was measured using the Pierce LDH cytotoxicity assay and cell viability measured by MTT cell proliferation assay.

NBT assay measuring the ROS level

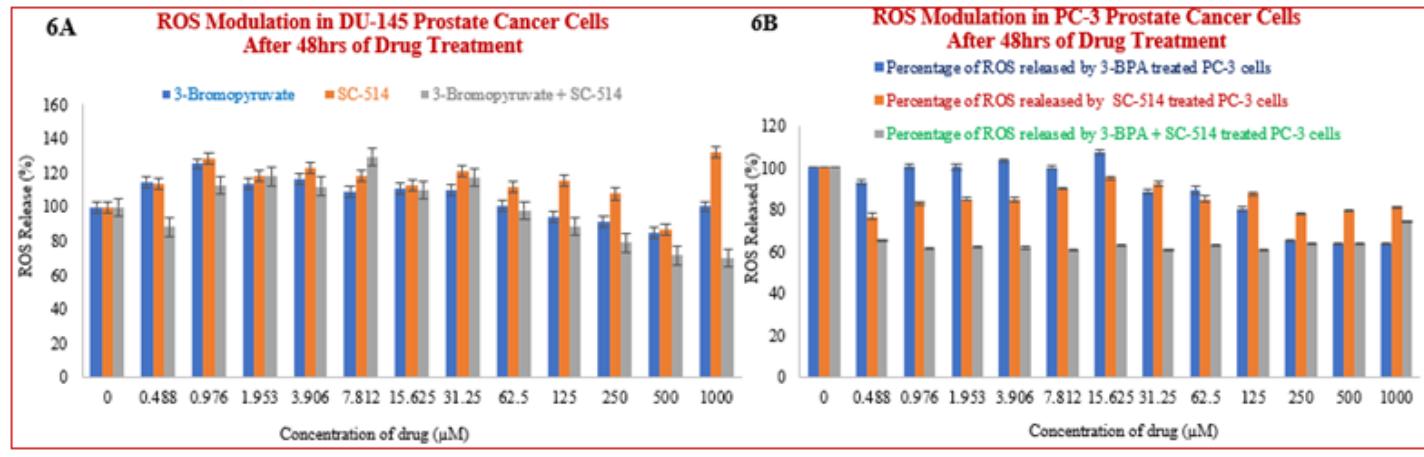

Figure 6 (A) NBT assay results showing treatment-induced inhibition of SOD/ROS production in DU-I45 prostate cancer cells. Cells were treated as described earlier and subjected to the NBT assay for ROS determination. The results indicated no statistical differences (P> 0.05) between the different treatment regimens at all concentration points. The results/data points were the means of six independent experiments performed in triplicates. Figure 6 (B) NBT assay results showing treatment-induced inhibition of SOD/ROS production in PC-3 prostate cancer cells. Cells were treated as described earlier and subjected to the NBT assay for ROS determination. The results indicated statistical differences $(P<0.05)$ between the different treatment regimens at all concentration points. The results/data points were the means of six independent experiments performed in triplicates. 
Live red image-poly caspase detection assay in PC-3 cells

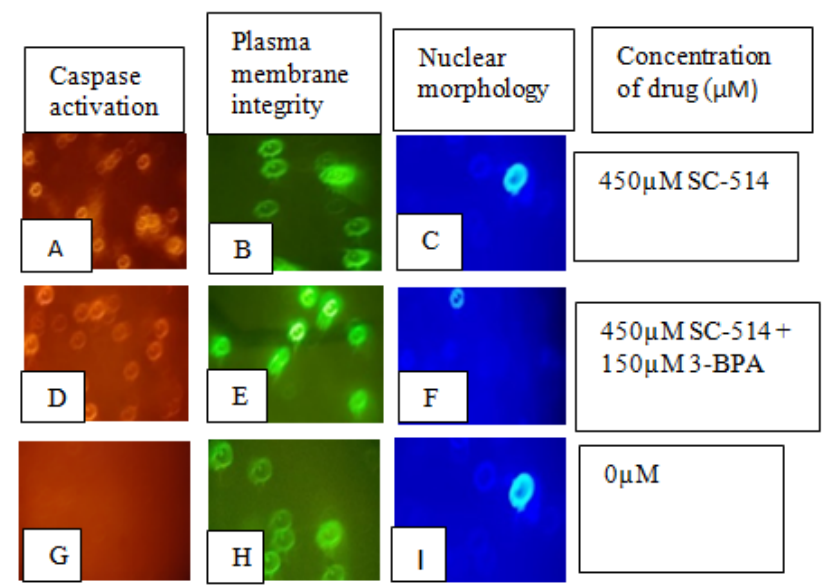

A

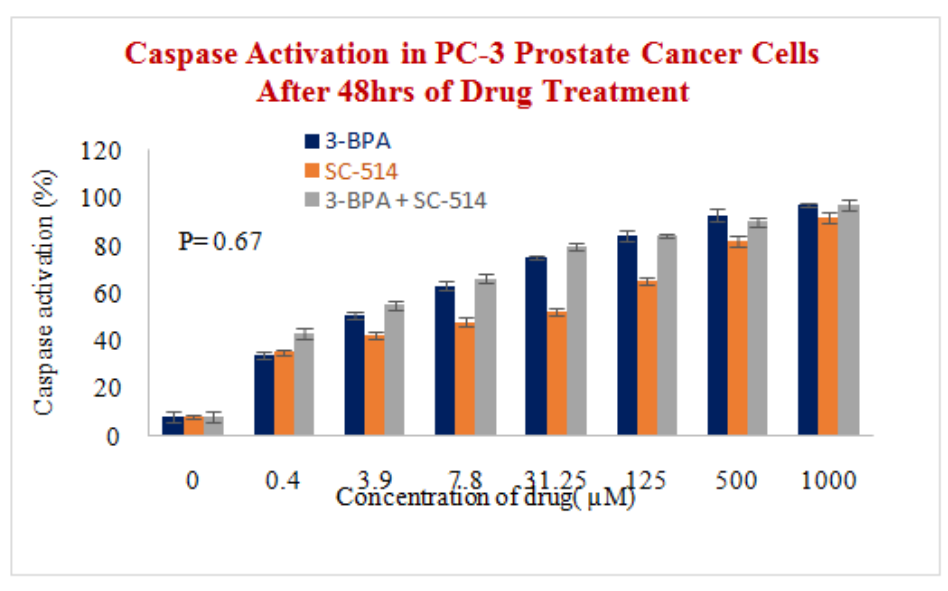

B

Image-iT TM LIVE Red Poly Caspases Detection in DU-I 45 cells (Figure 7C)

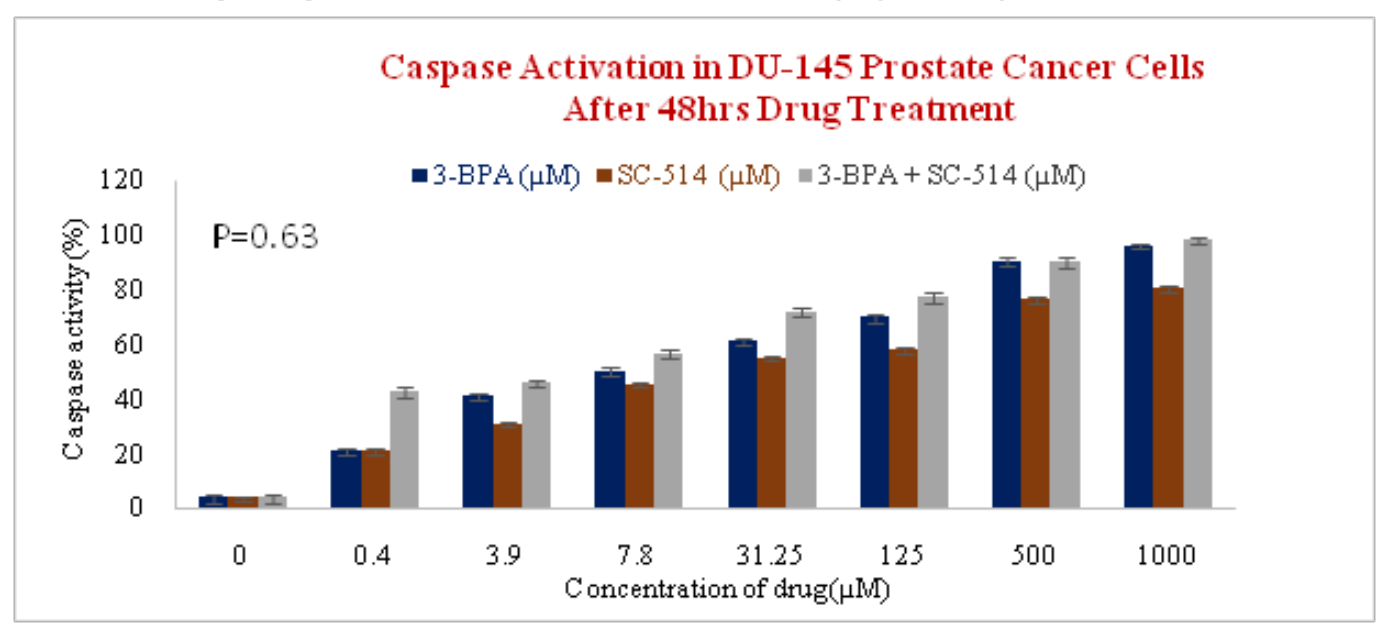

C

Figure 7 (A) Binding of SR-VAD-FMK FLICA to Prostate cancer cells that undergo apoptosis. PC-3 prostate cancer cells growing in 96 well plates were treated with 3-BPA, SC-5I4, and 3-BPA + SC-5I4 for $48 \mathrm{hrs}$. The cells were then incubated with fam-VAD-fmk as described in protocol. Cells were examined under a fluorescence microscope (Nikon eclipse E600) using incident fluorescence excitation with red fluorescence (caspase activation), green fluorescence (plasma membrane integrity) and blue fluorescence (nuclear morphology) released from treated cells. Magnification of images was 20x. Figure $\mathbf{7}$ (B) Caspase activation increases as concentration of drug treatment increases in PC-3 PCa cells. PC-3 cells were treated for $48 \mathrm{hrs}$ with varying concentrations of SC-5I4 $(0.488 \mu \mathrm{M}, 3.906 \mu \mathrm{M}, 7.8 \mathrm{I} 2 \mu \mathrm{M}, 3 \mathrm{I} .25 \mu \mathrm{M}, \mathrm{I} 25 \mu \mathrm{M}, 500 \mu \mathrm{M}, \mathrm{I} 000 \mu \mathrm{M}), 3-\mathrm{BPA}(0.488 \mu \mathrm{M}, 3.906 \mu \mathrm{M}, 7.8 \mathrm{I} 2 \mu \mathrm{M}, 3 \mathrm{I} .25 \mu \mathrm{M}, \mathrm{I} 25 \mu \mathrm{M}, 500 \mu \mathrm{M}, \mathrm{I} 000 \mu \mathrm{M})$, and 3-BPA + SC-5I4: I I $0 \mu \mathrm{M}$ 3-BPA (IC-50) and varying concentration of SC-5I4 $(0.488 \mu \mathrm{M}, 3.906 \mu \mathrm{M}, 7.8 \mathrm{I} 2 \mu \mathrm{M}, 3 \mathrm{I} .25 \mu \mathrm{M}, \mathrm{I} 25 \mu \mathrm{M}, 500 \mu \mathrm{M}$, I000 $\mu \mathrm{M})$ Figure 7 (C) Caspase activation increases as concentration of drug treatment increases in DU-I45 PCa cells. DU-I45 prostate cells were treated for 48hrs with varying concentrations of SC$5 \mathrm{I} 4(0.488 \mu \mathrm{M}, 3.906 \mu \mathrm{M}, 7.8 \mathrm{I} 2 \mu \mathrm{M}, 3 \mathrm{I} .25 \mu \mathrm{M}, \mathrm{I} 25 \mu \mathrm{M}, 500 \mu \mathrm{M}, \mathrm{I} 000 \mu \mathrm{M}), 3-\mathrm{BPA}(0.488 \mu \mathrm{M}, 3.906 \mu \mathrm{M}, 7.8 \mathrm{I} 2 \mu \mathrm{M}, 3 \mathrm{I} .25 \mu \mathrm{M}, \mathrm{I} 25 \mu \mathrm{M}, 500 \mu \mathrm{M}, \mathrm{I} 000 \mu \mathrm{M})$, and 3-BPA + SC-5I4: II $0 \mu \mathrm{M} 3-B P A(I C-50)$ and varying concentration of SC-5I $4(0.488 \mu \mathrm{M}, 3.906 \mu \mathrm{M}, 7.8 \mathrm{I} 2 \mu \mathrm{M}, 3 \mathrm{I} .25 \mu \mathrm{M}, 125 \mu \mathrm{M}, 500 \mu \mathrm{M}, 1000 \mu \mathrm{M})$.

This study suggests that 3-BPA and/or SC-514 treatment can inhibit prostate cancer carcinogenesis. The combination treatment of 3-BPA and SC-514 was more effective in inhibiting prostate cancer cell proliferation compared to the monotreatment of either 3-BPA or SC-514 as shown in Figure 4A and Figure 4B. Figure 4A shows a dose-dependent effect for the combined drug treatment, while Figure 4B shows no clear dose-dependence. There is a possible explanation for this observation. The cell line used in figure 4B is DU-145 prostate cancer cell line while the cell line used in figure 4A is PC-3 prostate cancer cell line. DU-145 prostate cancer cell has an active nuclear factor kappa light chain enhancer of activated B cells (NF-KB) receptor, which is not as active in PC-3 prostate cancer cells. ${ }^{84}$ The NF-KB receptor in DU-145 prostate cancer cells could be interfering with the activity of the drugs (3-BPA and SC-514) in the combination treatment. This is highly possible since SC-514 works by inhibiting NF-KB. Overexpression of NF-KB receptor in DU-145 prostate cancer cells potentially hinders/impacts the mechanism of action of SC-514 drug in DU-145 prostate cancer cells.

The interaction between 3-BPA and SC-514 was synergistic in DU-145 and PC-3 prostate cancer cells as calculated from Loewe additivity model and combination index..$^{85}$ Comparison of LDH cytotoxicity and MTT cell viability results in figures $5 \mathrm{~A}-5 \mathrm{~F}$ further confirm the cytotoxicity effect of 3-BPA and/or SC-514 on prostate cancer cells. The result show that as cell proliferation decreased the quantity of lactate dehydrogenase $(\mathrm{LDH})$ released into the culture media from damaged prostate cancer cells increased at most treatment 
concentrations. The LDH released serve as a biomarker for cellular cytotoxicity and cytolysis of the drug treated DU-145 and PC-3 prostate cancer cells. ${ }^{86,87}$ The combination of these two assays provide a safe alternative to radioactive cytotoxicity assays.

LDH cytotoxicity level in DU-145 cells treated with combination of 3-BPA and SC-514 (Figure 5C) did not impact the highest level of cytotoxicity at all concentrations when compared to the single treatment of 3-BPA(Figure 5A) or SC-514 (Figure 5B). Similarly, LDH cytotoxicity level in PC-3 cells treated with combination of 3-BPA and SC-514 (Figure 5F) did not impacted highest level of cytotoxicity at all concentrations when compared to the single treatment of 3-BPA (Figure 5D) or SC-514 (Figure 5E). This observation suggests that there are other mechanisms of actions used by these 3-BPA and/or SC514. These undiscovered mechanisms may not involve destruction of cell membrane and leakage of lactate dehydrogenase enzymes to the extra-cellular spaces. For example, shrinking of the prostate cancer cells in manner that allow other cell contents to be released more than the release of lactate dehydrogenase enzymes. The synergistic effect observed earlier could have occurred as result multiple mechanisms that are not fully understood. Future studies will use other cell viability assays such as alamar Blue and cell titer glo to confirm this suggestion.

MTT cell viability in DU-145 prostate cancer cells indicated the lowest level at combination treatment of 3-BPA and SC-514 (Figure $5 \mathrm{C}$ ) when compared to the single treatment of 3-BPA (Figure $5 \mathrm{~A}$ ) or SC-514 (Figure 5B). Similarly, MTT cell viability in PC-3 prostate cancer cells indicated the lowest level at combination treatment of $150 \mu \mathrm{M} 3-\mathrm{BPA}$ and $1000 \mu \mathrm{M} \mathrm{SC}-514$ (Figure $5 \mathrm{~F}$ ) when compared to the single treatment of $1000 \mu \mathrm{M} 3$-BPA (Figure 5D) or $1000 \mu \mathrm{M} \mathrm{SC}$ 514 (Figure 5E). However, the over all trend of cell viability in PC-3 prostate cancer cells do not show that the combination treatment of 3-BPA and SC-514 impacted the lowest level of cell viability at all concentrations. For example, the combination treatment of $150 \mu \mathrm{M}$ 3 -BPA and $125 \mu \mathrm{M} \mathrm{SC}-514$ in PC-3 recorded higher cell viability when compared to the single treatment of $125 \mu \mathrm{M} 3$-BPA or $125 \mu \mathrm{M} \mathrm{SC}-514$ This may be as result of resistance to the combination treatment at 125 $\mu \mathrm{M}$ concentration.

Results from the NBT assay suggests that ROS induction only cannot account for the mechanism of action of 3-BPA and/or SC-514. ROS modulation in DU-145 and PC-3 prostate cancer cells indicated a weak correlation between ROS released and concentration of 3-BPA and/or SC-514 (Figure 6A \& Figure 6B). However, SC-514 monotreatment induced elevated level of ROS at $125 \mu \mathrm{M}$ concentration and higher concentrations. Oxidative stress in cells could mean that the ROS is too low or too high. In this study, 3-BPA at low concentrations $(0.48 \mu \mathrm{M}-62.5 \mu \mathrm{M})$ appears to work by increasing the ROS levels, ${ }^{88,89}$ but 3 -BPA at higher concentrations $(62.5 \mu \mathrm{M}-1000 \mu \mathrm{M})$ appears to work by decreasing the ROS levels..$^{90}$ On the other hand, higher

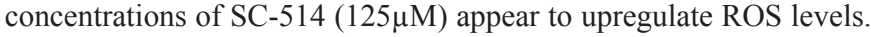
This conflicting effect between 3-BPA and SC-514 explains why the combination treatment (SC-514 + 3-BPA) gave a lower ROS level compared to the single treatment with either 3-BPA or SC-514. The ROS modulation result shows that the interaction between the 3-BPA and SC-514 is not through ROS only. The synergistic effect between 3-BPA and SC-514 could be through a mechanism that is not directly linked to ROS induction. Future studies will elucidate the mechanism/s of action that may be involved. Survival pathways such as NF-KB pathway, IL-6 pathway and AKt-p13 pathway can be investigated to further understand the mechanism of action of 3-BPA and/or SC-514.
It appears that combination of 3-BPA and SC-514 was more effective than SC-514 monotreatment in inducing apoptosis in DU-145 and PC-3 prostate cancer cells (Figure 7A-7C). But the combination treatment of 3-BPA and SC-514 did not induce apoptosis more than 3-BPA monotreatment at most concentration in DU-145 and PC-3 prostate cancer cells (Figure 7A-7C). 3-BPA appears to induce more apoptosis than SC-514 in DU-145 and PC-3 cells at most concentrations as indicated by caspase activation assay (Figure 7A-7C). However, other modes of cell death may exist with SC-514 drug treatment that may make SC-514 therapeutically more effective than 3-BPA. Future studies will investigate modes of cells deaths such as necrosis, autophagy, necroptosis, and ferroptosis in prostate cancer cells treated with 3-BPA and/or SC-514. ${ }^{91}$

The existence of multidrug resistance (MDR) may influence the mode of cell deaths or survival pathways in prostate cancer cells as mentioned above. Metabolic activities of prostate cancer cells favor the sustained production of ATP energy required for MDR (Figure 2). Specifically, catabolic activity in prostate cancer cells produces ATP from break down of fats proteins and carbohydrate (Figure 3). MDR occurs when ATP Binding Cassette (ABC) proteins use the ATP energy produced to pump drug from inside of the prostate cancer cells to the extracellular surroundings of the prostate cancer cells. Future studies will investigate the role of BCL2 family on ABC proteinsmediated MDR during the treatment of prostate cancer with 3-BPA and/or SC-514.

Furthermore, drug delivery of 3-BPA and/or SC-514 will be explored for better therapeutic efficiency, reduction of MDR and better treatment outcome because nanoparticle drug delivery systems (NDDS) are effective in delivering anti-cancer drugs such as 3-BPA and/or SC-514 to prostate cancer. ${ }^{2,92,93}$

\section{Conclusion}

In conclusion, combination treatment remains a viable option when conventional monotherapy fails. Results from combination of 3-BPA and SC-514 in prostate cancer therapy will potentially encourage further combination possibilities between other chemotherapeutic drugs.

\section{Acknowledgements}

The authors are grateful to Dr Gregg B Fields for his helpful comments on this article. We appreciate Dr James Hartmann for reviewing and correcting a section this article. We appreciate the statistical guidance from Dr Erik Noonburg. We appreciate FAU graduate college for funding through graduate fellowships. We also appreciate department of Biological Sciences FAU for funding through Vincent Saurino Fellowship.

\section{Conflict of interest}

Author declares that there is no conflict of interest.

\section{References}

1. Liu Y. Fatty acid oxidation is a dominant bioenergetic pathway in prostate cancer. Prostate Cancer Prostatic Dis. 2006;9(3):230-234.

2. Chaudhary S, Umar A, Mehta SK. Surface functionalized selenium nanoparticles for biomedical applications. J Biomed Nanotechnol. 2014;10(10):3004-3042.

3. Applegate C, Rowles J, Ranard K, et al. Soy Consumption and the Risk of Prostate Cancer: An Updated Systematic Review and Meta-Analysis. Nutrients. 2018;10(1):E40. 
4. Jemal A. Cancer Statistics. Cancer J Clin. 2009;59:225-249.

5. Hanahan D, Weinberg RA. Hallmarks of Cancer: The Next Generation. Cell. 2011;144(5):646-674.

6. Yuan Y. Glutathione-mediated release of functional miR-122 from gold nanoparticles for targeted induction of apoptosis in cancer treatment. $J$ Nanosci Nanotechnol. 2014;14(8):5620-5627.

7. Siegel R, Naishadham D. Cancer statistics. CA A Cancer J. 2013;63:1130 .

8. Nazir S, Hussain T, Ayub A, et al. Nanomaterials in combating cancer: Therapeutic applications and developments. Nanomedicine Nanotechnology Biol Med. 2014;10:19-34.

9. Oyelere A. Gold nanoparticles: From nanomedicine to nanosensing. Nanotechnol Sci Appl. 2008;1:45-66.

10. Muthu MS, Singh S. Targeted nanomedicines: effective treatment modalities for cancer, AIDS and brain disorders. Nanomedicine (Lond). 2009;4(1):105-118.

11. SM Janib, AS Moses, AA MacKay. Imaging and drug delivery using theranostic nanoparticles. Adv Drug Deliv Rev. 2010;62(11):1052-1063.

12. A Al-Mamgani. Controversies in the treatment of high-risk prostate cancer - What is the optimal combination of hormonal therapy and radiotherapy: A review of literature. Prostate. 2010;70(7):701-709.

13. A Dal Pra, FL Cury, L Souhami. Combining radiation therapy and androgen deprivation for localized prostate cancer - a critical review. Curr Oncol. 2010;17(5):28-38.

14. CM Moore, D Pendse, M Emberton. Photodynamic therapy for prostate cancer--a review of current status and future promise. Nat Clin Pr Urol. 2009;6(1):18-30.

15. M Kohli, DJ Tindall. New developments in the medical management of prostate cancer. Mayo Clin Proc. 2010;85(1):77-86.

16. AVD Amico. Adjuvant versus salvage radiation therapy for prostate cancer and the risk of death. BJU Int. 2010;106(11):1618-1622.

17. M Roscigno. Medical therapy of prostate cancer. A review. Minerva Urol Nefrol. 2005;57(2):71-84.

18. TM Beer, JS Bubalo. Complications of chemotherapy for prostate cancer Semin Urol Oncol. 2001;19(3):222-230.

19. A Heidenreich, $\mathrm{R}$ von Knobloch, $\mathrm{R}$ Hofmann. Current status of cytotoxic chemotherapy in hormone refractory prostate cancer. Eur Urol. 2001;39(2):121-130.

20. M Pomerantz, P Kantoff. Advances in the treatment of prostate cancer. Annu Rev Med. 2007;58:205-220.

21. RJ Amato, BS Teh, H Henary, et al. A retrospective review of combination chemohormonal therapy as initial treatment for locally advanced or metastatic adenocarcinoma of the prostate. Urol Oncol. 2009;27(2):165169.

22. M Letsch, AV Schally, K Szepeshazi, et al. Effective treatment of experimental androgen sensitive and androgen independent intraosseous prostate cancer with targeted cytotoxic somatostatin analogue AN-238. J Urol. 2004;171(2 Pt1):911-915.

23. MP Edlind, AC Hsieh. PI3K-AKT-mTOR signaling in prostate cancer progression and androgen deprivation therapy resistance. Asian J Androl. 2014;16(3):378-386

24. T Fiaschi. Reciprocal metabolic reprogramming through lactate shuttle coordinately influences tumor-stroma interplay. Cancer Res 2012;72(19):5130-5140

25. SC Casey, Amedei A, Aquilano K, et al. Cancer prevention and therapy through the modulation of the tumor microenvironment. Semin Cancer Biol. 2015;35 Suppl:S199-S223.
26. P Dell' Antone. Energy metabolism in cancer cells: How to explain the Warburg and Crabtree effects? Med Hypotheses. 2012;79(3):388-392.

27. P Lis. The HK2 dependent "Warburg effect" and mitochondrial oxidative phosphorylation in cancer: Targets for effective therapy with 3-bromopyruvate. Molecules. 2016; 21(12):E1730.

28. A Zorzano, C Fandos, M Palacín. Role of plasma membrane transporters in muscle metabolism. Biochem J. 2000;349 Pt 3:667-688.

29. BMM Zwaans, DB Lombard. Interplay between sirtuins, MYC and hypoxia-inducible factor in cancer-associated metabolic reprogramming. Dis Model Mech. 2014;7(9):1023-1032.

30. C Pinheiro. Role of monocarboxylate transporters in human cancers: State of the art. J Bioenerg Biomembr. 2012;44(1):127-139.

31. I Sadowska-Bartosz, M Soszyński, S Ułaszewski, et al. Transport of 3-bromopyruvate across the human erythrocyte membrane. Cell Mol Biol Lett. 2014;19(2):201-214.

32. YH Ko, PL Pedersen, JF Geschwind. Glucose catabolism in the rabbi VX2 tumor model for liver cancer: Characterization and targeting hexokinase. Cancer Lett. 2001;173(1):83-91.

33. RS Kaplan, RD Pratt, PL Pedersen. Purification and characterization of the reconstitutively active phosphate transporter from rat liver mitochondria. J Biol Chem. 1986;261(27):12767-12773.

34. S Cardaci, E Desideri, MR Ciriolo. Targeting aerobic glycolysis: 3-Bromopyruvate as a promising anticancer drug. J Bioenerg Biomembr. 2012;44(1):17-29.

35. M Signore, L Ricci-Vitiani, R De Maria. Targeting apoptosis pathways in cancer stem cells. Cancer Lett. 2013;332(2):374-382.

36. S Ganapathy-Kanniappan. Glyceraldehyde-3-phosphate dehydrogenase (GAPDH) is pyruvylated during 3-bromopyruvate mediated cancer cell death. Anticancer Res. 2009;29(12):4909-4918.

37. C Mulet, F Lederer. Bromopyruvate as an Affinity Label for Baker's Yeast Flavocytochrome b2 Kinetic Study of the Inactivation Reaction. Eur J Biochem. 1977;73(2):443-447.

38. JA Menendez, T Alarcón. Metabostemness: a new cancer hallmark Front Oncol. 2014;4:262.

39. L MacChioni. Mitochondrial dysfunction and effect of antiglycolytic bromopyruvic acid in GL15 glioblastoma cells. J Bioenerg Biomembr. 2011;43(5):507-518.

40. A DA Paula Pereira Silva. Inhibition of energy-producing pathways of HepG2 cells by 3-bromopyruvate 1. Biochem J. 2009;417(3):717-726.

41. YH Ko, Smith BL, Wang Y, et al. Advanced cancers: Eradication in all cases using 3-bromopyruvate therapy to deplete ATP. Biochem. Biophys Res Commun. 2004;324(1):269-275.

42. JFH. Geschwind, YH Ko, MS Torbenson, et al. Novel therapy for liver cancer: direct intraarterial injection of a potent inhibitor of ATP production. Cancer Res. 2002;62(14):3909-3913.

43. M Buijs. Specificity of the anti-glycolytic activity of 3-bromopyruvate confirmed by FDG uptake in a rat model of breast cancer. Invest. New Drugs. 2009;27(2):120-123.

44. SM El Sayed, El-Magd RM, Shishido Y, et al. D-amino acid oxidaseinduced oxidative stress, 3-bromopyruvate and Citrate inhibit angiogenesis, exhibiting potent anticancer effects. J Bioenerg Biomembr. 2012;44(5):513-523.

45. A Nakano, Tsuji D, Miki H, et al. Glycolysis inhibition inactivates ABC transporters to restore drug sensitivity in malignant cells. PLoS One. 2011;6(11):e27222.

46. Yu SJ, Yoon JH, Yang JI, et al. Enhancement of hexokinase II inhibitorinduced apoptosis in hepatocellular carcinoma cells via augmenting ER stress and anti-angiogenesis by protein disulfide isomerase inhibition. $J$ Bioenerg Biomembr. 2012;44(1):101-115. 
47. Wu L, Xu J, Yuan W, et al. The reversal effects of 3-bromopyruvate on multidrug resistance In Vitro and In Vivo derived from human breas MCF-7/ADR Cells. PLoS One. 2014;9(11):e112132.

48. Isayev $\mathrm{O}$, Rausch $\mathrm{V}$, Bauer $\mathrm{N}$, et al., Inhibition of glucose turnover by 3-bromopyruvate counteracts pancreatic cancer stem cell features and sensitizes cells to gemcitabine. Oncotarget. 2014;5(13):5177-5189.

49. LS Ihrlund, E Hernlund, O Khan, et al. 3-Bromopyruvate as inhibitor of tumour cell energy metabolism and chemopotentiator of platinum drugs. Mol Oncol. 2008;2(1):94-101.

50. JS Kim et al., Role of reactive oxygen species-mediated mitochondrial dysregulation in 3-bromopyruvate induced cell death in hepatoma cells: RROS-mediated cell death by 3-BrPA. J Bioenerg Biomembr. 2008;40(6):607-618.

51. S Ganapathy-Kanniappan, Geschwind JF, Kunjithapatham R, et al., 3-Bromopyruvate induces endoplasmic reticulum stress, overcomes autophagy and causes apoptosis in human HCC cell lines. Anticancer Res. 2010;30(3):923-935.

52. D Valenti, RA Vacca, L de Bari. 3-Bromopyruvate induces rapid human prostate cancer cell death by affecting cell energy metabolism, GSH poo and the glyoxalase system. J Bioenerg Biomembr. 2015;47(6):493-506.

53. Y Eguchi, S Shimizu, Y Tsujimoto. Intracellular ATP Levels Determine Cell Death Fate by Apoptosis or Necrosis1. Cancer Res. 1997;57(10):1835-1840.

54. D Valenti, RA Vacca, L de Bari. 3-Bromopyruvate induces rapid human prostate cancer cell death by affecting cell energy metabolism, GSH pool and the glyoxalase system. J Bioenerg Biomembr. 2015;47(6):493-506.

55. SY Proskuryakov, AG Konoplyannikov, VL Gabai. Necrosis: A specific form of programmed cell death? Exp Cell Res. 2003;283(1):1-16.

56. YH Ko, Verhoeven HA, Lee MJ, et al. A translational study "case report" on the small molecule "energy blocker" 3-bromopyruvate (3BP) as a potent anticancer agent: From bench side to bedside. $J$ Bioenerg Biomembr. 2012;44(1):163-170.

57. El Sayed SM, Mohamed WG, Seddik MA, et al, Safety and outcome of treatment of metastatic melanoma using 3-bromopyruvate: a concise literature review and case study. Chin J Cancer. 2014;33(7):356-364.

58. JF Geschwind, YH Ko, MS Torbenson, et al. Novel therapy for liver cancer: direct intraarterial injection of a potent inhibitor of ATP production. Cancer Res. 2002;62(14):3909-3913.

59. Kishore N, Sommers C, Mathialagan S, et al. A selective IKK-2 inhibitor blocks NF- $\kappa \mathrm{B}$-dependent gene expression in interleukin-1 $\beta$-stimulated synovial fibroblasts. J Biol Chem. 2003;278(35):32861-32871.

60. MK Choo, H Sakurai, DH Kim, et al. A ginseng saponin metabolite suppresses tumor necrosis factor-??-promoted metastasis by suppressing nuclear factor-??B signaling in murine colon cancer cells. Oncol Rep. 2008;19(3):595-600.

61. A Gagnon, A Landry, A Sorisky. IKKbeta and the anti-adipogenic effect of platelet-derived growth factor in human abdominal subcutaneous preadipocytes. $J$ Endocrinol. 2009;201(1):75-80.

62. J Hwang, HJ Lee, WH Lee, et al. NF-B as a common signaling pathway in ganglioside-induced autophagic cell death and activation of astrocytes. J Neuroimmunol. 2010;226(1-2):66-72.

63. DM Hwang, Kundu JK, Shin JW, et al. cis-9,trans-11-Conjugated linoleic acid down-regulates phorbol ester-induced NF-??B activation and subsequent COX-2 expression in hairless mouse skin by targeting Ikappa B kinase and PI3K-Akt. Carcinogenesis. 2007;28(2):363-371.

64. SJ Jeong, CA Pise-Masison, MF Radonovich, et al. A novel NF- $\kappa B$ pathway involving IKK $\beta$ and p65/RelA Ser-536 phosphorylation results in p53 inhibition in the absence of NF- $\kappa \mathrm{B}$ transcriptional activity. $J$ Biol Chem. 2005;280(11):10326-10332.
65. X Lu, PG Moore, H Liu, et al. Phosphorylation of ARC Is a critical element in the antiapoptotic effect of anesthetic preconditioning. Anesth Analg. 2011;112(3):525-531.

66. Oenema TA, Kolahian S, Nanninga JE, et al. Pro-inflammatory mechanisms of muscarinic receptor stimulation in airway smooth muscle. Respir Res. 2010;11:130.

67. MK Rasmussen et al., IL-8 and p53 are inversely regulated through JNK, p38 and NF-kappa B p65 in HepG2 cells during an inflammatory response. Inflamm Res. 2008;57(7):329-339.

68. MM Syed, NK Phulwani, T Kielian. Tumor necrosis factor-alpha (TNFalpha) regulates Toll-like receptor 2 (TLR2) expression in microglia. $J$ Neurochem. 2007;103(4):1461-1471.

69. WL Thompson, LJ Van Eldik. Inflammatory cytokines stimulate the chemokines CCL2/MCP-1 and CCL7/MCP-7 through NFאB and MAPK dependent pathways in rat astrocytes. Brain Res. 2009;1287:47-57.

70. Tse AK, Chen YJ, Fu XQ, et al. Sensitization of melanoma cells to alkylating agent-induced DNA damage and cell death via orchestrating oxidative stress and IKK $\beta$ inhibition. Redox Biol. 2017;11:562-576.

71. Kishore N1, Sommers C, Mathialagan S, et al. A selective IKK-2 inhibitor blocks NF-kappa B-dependent gene expression in interleukin-1 beta-stimulated synovial fibroblasts. J Biol Chem. 2003;278(35):3286132871 .

72. J Napetschnig, H Wu. Molecular Basis of NF-кB Signaling. Annu Rev Biophys. 2013;42:443-468.

73. Sakamoto K, Hikiba Y, Nakagawa H, et al. Promotion of DNA repair by nuclear IKK $\beta$ phosphorylation of ATM in response to genotoxic stimuli. Oncogene. 2013;32(14):1854-1862.

74. ZH Wu, Y Shi, RS Tibbetts, et al. Molecular linkage between the kinase ATM and NF-kappaB signaling in response to genotoxic stimuli. Science. 2006;311(5764):1141-1146.

75. FS Lee, RT Peters, LC Dang, et al. MEKK1 activates both IkappaB kinase alpha and IkappaB kinase beta. Proc Natl Acad Sci USA. 1998;95(16):9319-9324.

76. Mercurio F, Zhu H, Murray BW, et al. IKK-1 and IKK-2: cytokineactivated IkappaB kinases essential for NF-kappaB activation. Science. 1997;278(5339):860-866.

77. Nakano H, Shindo M, Sakon S, et al. Differential regulation of IkappaB kinase alpha and beta by two upstream kinases, NF-kappaB-inducing kinase and mitogen-activated protein kinase/ERK kinase kinase-1. Proc Natl Acad Sci USA. 1998;95(7):3537-3542.

78. MJ Yin. HTLV-I tax protein binds to MEKK1 to stimulate I $\kappa \mathrm{B}$ kinase activity and NF- $\mathrm{KB}$ activation. Cell. 1998;93(5):P875-884.

79. E Zandi, Y Chen, M Karin. Direct Phosphorylation of IB by IKK and IKK: Discrimination Between Free and NF-B-Bound Substrate. Science. 1998;281(5381):1360-1363.

80. Liu Q, Wu H, Chim SM, et al. SC-514, a selective inhibitor of IKK?? attenuates RANKL-induced osteoclastogenesis and NF-?? B activation. Biochem Pharmacol. 2013;86(12):1775-1783.

81. Kobori M, Yang Z, Gong D, et al. Wedelolactone suppresses LPSinduced caspase-11 expression by directly inhibiting the IKK Complex. Cell Death Differ. 2004;11(1):123-130.

82. Paccez JD, Vasques GJ, Correa RG, et al. The receptor tyrosine kinase Ax is an essential regulator of prostate cancer proliferation and tumor growth and represents a new therapeutic target. Oncogene. 2013;32(6):689-698.

83. L Huang, Y Jiang, Y Chen. Predicting Drug Combination Index and Simulating the Network-Regulation Dynamics by Mathematical Modeling of Drug-Targeted EGFR-ERK Signaling Pathway. Sci Rep. 2017. 
84. Gasparian AV, Yao YJ, Kowalczyk D, et al., The role of IKK in constitutive activation of NF-kappaB transcription factor in prostate carcinoma cells. J Cell Sci. 2002;115(Pt 1):141-51.

85. L Ma, M Kohli, A Smith. Nanoparticles for combination drug therapy. ACS Nano. 2013;7(11):9518-9525.

86. I Hassan, Azmat Ali Khan, Shazia Aman, et al. Restrained management of copper level enhances the antineoplastic activity of imatinib in vitro and in vivo. Sci Rep. 2018.

87. Zou X, Kwon SH, Jiang K, et al. Renal scattered tubular-like cells confer protective effects in the stenotic murine kidney mediated by release of extracellular vesicles. Sci Rep. 2018;8(1):1263.

88. Zhang Q, Zhang Y, Zhang P,et al., Hexokinase II inhibitor, 3-BrPA induced autophagy by stimulating ROS formation in human breast cancer cells. Genes Cancer. 2014;5(3-4):100-112.

89. Rodrigues-Ferreira C, Da Silva APP, Galina A. Effect of the antitumoral alkylating agent 3-bromopyruvate on mitochondrial respiration: Role of mitochondrially bound hexokinase. J Bioenerg Biomembr. 2012;44(1):39-49.
90. Yadav S, Kujur PK, Pandey SK, et al.Antitumor action of 3-bromopyruvate implicates reorganized tumor growth regulatory components of tumor milieu, cell cycle arrest and induction of mitochondria-dependent tumor cell death. Toxicol Appl Pharmacol. 2018;339:52-64.

91. Martin-Sanchez D, Fontecha-Barriuso M, Sanchez-Niño MD, et al., Cell death-based approaches in treatment of the urinary tract-Associated diseases: A fight for survival in the killing fields review-Article. Cell Death Dis. 2018;9(2):118.

92. SB Sun, P Liu, FM Shao, et al. Formulation and evaluation of PLGA nanoparticles loaded capecitabine for prostate cancer. Int $J$ Clin Exp Med. 2015;8(10):19670-19681.

93. A Michael, K Syrigos, H Pandha. Prostate cancer chemotherapy in the era of targeted therapy. Prostate Cancer Prostatic Dis. 2009;12:13-16. 